\title{
Panel debates next Farm Bill's impact on California
}

Editor's note: This roundtable discussion features the voices of three prominent authorities on the 2007 Farm Bill. Their freewheeling 90-minute discussion took place in the summer of 2005. While participants did not reach consensus on all points, each approved this summary of the discussion and their remarks.

California Agriculture Associate Editor Alvin D. Sokolow moderated the session and wrote the narrative.

If $^{a t}$ all goes as scheduled, the next federal Farm Bill will be approved by Congress and the President late in 2007. Each Farm Bill updates national agricultural policy, every 5 years or so. The Farm Bill covers a wide swath of programs, regulations and spending — including commodity payments, nutrition, conservation, rural development, energy, trade, research and extension, credit, and forestry. The 2002 legislation authorized a 5-year total of $\$ 422$ billion.

What are the key issues affecting California in the 2007 Farm Bill? California Agriculture organized a roundtable of panelists to address this question:

- Ralph E. Grossi, President, Washington, D.C.based American Farmland Trust since 1985; third-generation Marin County dairy farmer.

- A.G. Kawamura, Secretary, California Department of Food and Agriculture since 2003; Orange County producer of specialty crops.

- Daniel A. Sumner, Director, UC Agricultural Issues Center (AIC); Frank Buck Jr. Professor, Department of Agricultural and Resource Economics, UC Davis.

\section{California's stake in upcoming Farm Bill}

California is the nation's leading agricultural state in market value of farm products, with annual on-farm revenue of about $\$ 30$ billion. Enhancing agriculture's ability to deliver food, fiber and other products to consumers, while improving the industry's social and environmental performance, is a key objective of the Farm Bill. Panelist Sumner noted that proposals for the 2007 bill include reducing farm commodity payments, supporting removal of export barriers, enhancing control of invasive agricultural pests and diseases, increasing incentives for conservation, and improving nutrition education and information.

Kawamura: In this Farm Bill, you have got new players that want to strengthen the nation's commitment to food security. There is the biotech community; the nutrition community, driven by the obesity crisis and other concerns; the conservation community, which is excited about the fact that there may be more dollars to achieve

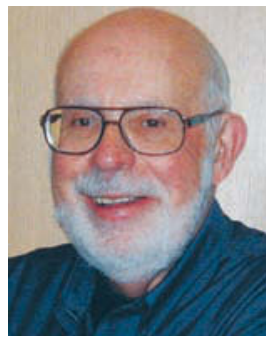

Alvin D. Sokolow

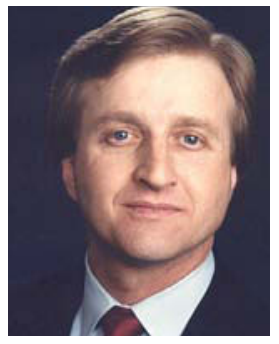

Ralph E. Grossi

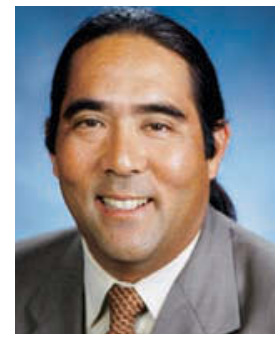

A.G. Kawamura

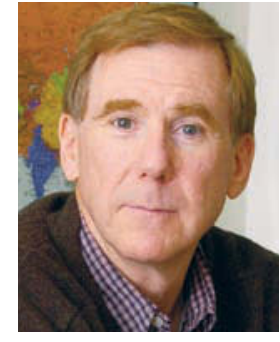

Daniel A. Sumner environmental purposes; and the bio-fuel energy community, which would love nothing more than a commitment to move toward energy self-sufficiency.

Grossi: At the top of that list is helping farmers and ranchers address conservation and environmental needs.

\section{Redirecting commodity payments}

A popular perception of federal farm policy in this state is that California gets short-changed in the billions of dollars spent nationally on subsidies to growers. Most of those funds go to a few basic crops - especially corn, wheat, soybeans, cotton and rice - that are produced largely in the Midwest and South, bypassing California's large, diversified agriculture with its hundreds of specialty crops. California annually receives less than $5 \%$ of commodity payments while its farm market value represents more than $12 \%$ nationwide (table 1). Two-thirds of the commodity payments coming to this state go to producers of two crops, cotton and rice. Panelists discussed how tax dollars could be redirected to support agricultural entrepreneurship and innovation. They also recognized that commodity payments contribute to local economies in rural communities.

Sumner: I think even for the commodities that have been the recipients of the transfers, the evidence that payments have created long-term health for those industries just isn't there. For example, wheat has gotten billions of dollars of subsidies over the last 40 to 50 years, strawberries approximately zero. Has that meant that wheat has been the strong, healthy industry, and strawberries a weak one? The answer is absolutely not. So there is some evidence that you do not build the long-term health of agriculture with income transfers to producers.

Grossi: There may be a lot of reasons why California farmers are more market-focused and entrepreneurial as a group than farmers in the rest of the country. One reason is that we have not had a lot of farm subsidies. Subsidies tend to dampen the entrepreneurial spirit, because farmers tend to think about how to maximize payments. You have only to look at the change in Iowa over the last 40 or 50 years to realize how less diverse an economy it is, in large 


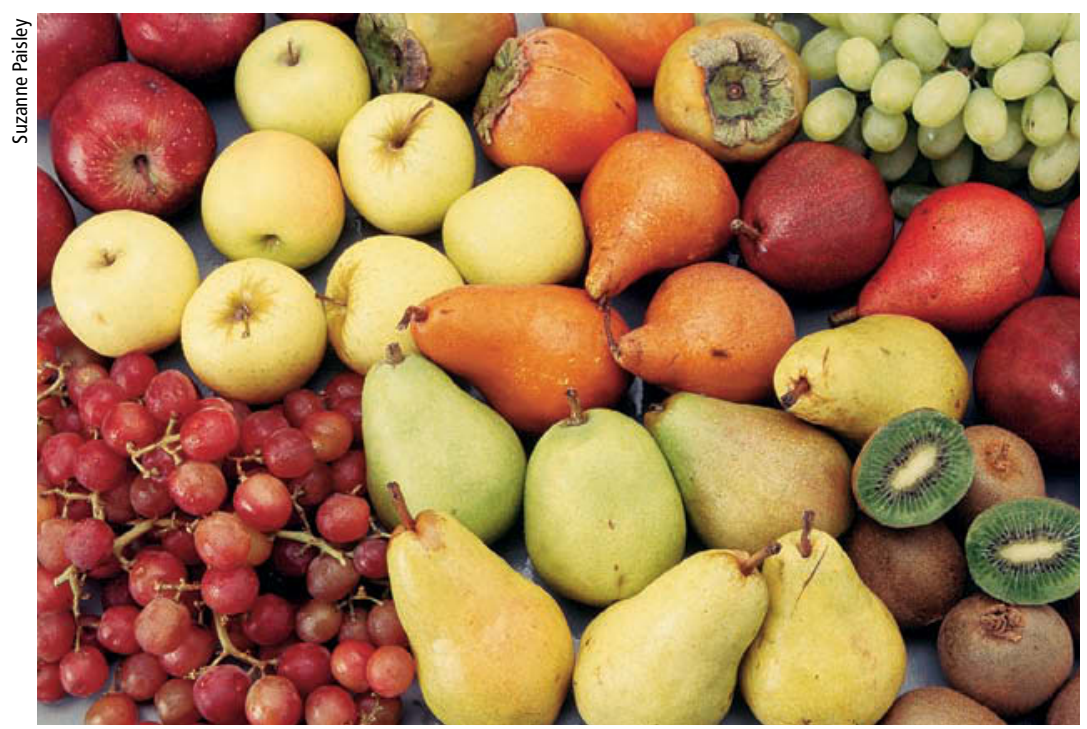

An innovative approach will be needed if the 2007 Farm Bill is to promote the growth and consumption of healthy fruits and vegetables, staples of California agriculture.

part because of farm subsidies. What we don't want to see in the next Farm Bill are California farmers wanting those same kinds of subsidies. I would like to see government support decoupled from specific

TABLE 1. States with top commodity payments versus total agricultural market value, FY 2003

\begin{tabular}{lcc}
\hline \hline State & $\begin{array}{l}\text { Commodity } \\
\text { payments* }\end{array}$ & $\begin{array}{c}\text { Farm products } \\
\text { market value }\end{array}$ \\
\hline Texas & $\ldots \ldots \ldots$ & $\$$ millions $\ldots \ldots \ldots \ldots$ \\
Arkansas & 9,641 & 17,966 \\
lowa & 900 & 5,900 \\
Illinois & 799 & 13,100 \\
Kansas & 762 & 9,200 \\
California & 742 & 10,300 \\
*Outlays fluctuate from year to year, mainly because of \\
changing commodity prices.
\end{tabular}
commodities, because it can have such a distorting influence on markets and individual farmer decisions.

Kawamura: However, the commodity payments that go to individual farmers also produce benefits. This money enables us to maintain our agricultural infrastructure and capacity nationally, helping farmers continue to stay in agriculture as opposed to letting their capacity sit idle. In small communities in Fresno and Tulare counties, and other places in California, there is still a dependency on agriculture doing well.

\section{Promoting better nutrition}

The Farm Bill also provides for food and nutrition programs, including food stamps, school lunch and food safety. Federal spending on these programs (about $\$ 50$ billion annually) actually exceeds commodity payments. Participants discussed the merits of promoting healthy diets among low-income and other consumers, an approach that would also benefit California agriculture (see page 8).

Kawamura: Nutrition has to be a global, national and statewide priority. We are excited about how nutrition awareness is growing, that this is the first and foremost investment that countries can make to promote a healthy citizenry. We are also recognizing the disaster we have in our own country, with obesity and over-eating, as well as malnutrition and hunger in America and other countries.

Sumner: The research we have done at the AIC shows that if people shifted their diets toward more fruits and vegetables, California agriculture gains substantially. It will require political leadership if we are to have a nutrition title that really focuses more attention on healthy eating.

Grossi: If you accept that large government programs and payments influence human behavior, then the Farm Bill has the potential to have a major impact on dietary habits. Should we have things in the bill that encourage institutional buyers to purchase different kinds of products? Milk instead of sodas, for example?

\section{Improving conservation programs}

California receives very little of the $\$ 1.8$ billion dollars in annual funding from the Conservation Reserve Program (CRP) which pays to idle cropland. California does better from other conservation programs (table 2). Participants commended funding for environmental improvement such as EQIP (Environmental Quality Incentives Program), as well as programs that offer technical assistance to farmers addressing environmental problems. EQIP received high marks because it assists agricultural landowners and operators on a cost-share basis to cope with water and air-quality issues.

Panelists pointed out that while everyone supports the concept of conservation, there is much to be done to improve the efficiency of programs. The CRP, for instance, is less useful to California agriculture because it isn't always reflective of conditions in the state: specifically, rents on land. While the CRP retires land, it does so on a more temporary basis through 10 -year contracts. It could be made more flexible by allowing sustainable harvesting of biomass for energy. Also in the research area, panelists said that federal funding to control pests and diseases should be expanded, increasing efforts to control the importation of pests through international trade channels.

Grossi: It's very important for us in agriculture to understand that regulation is not going to go away. We fight it at times, but we are living in an increasingly urban and suburban society, with more people living closer to agriculture, as urban sprawl increases. So, the real challenge here is to regulate wisely and balance this increasing regulatory burden with incentives and other compensatory programs that share the cost of achieving environmental goals between farmers who care for the land and the rest of society who reap the benefits.

Kawamura: In our department we see that the greater transfer of materials and plant species in world markets leaves California tremendously vulnerable. Pest exclusion and phytosanitary protocols need to be brought 
to the forefront in the Farm Bill, especially in a world where you have homeland security concerns as well.

\section{Enhancing global trade}

The 2007 Farm Bill has the potential to enhance the position of California agriculture in international trade. The panel noted that trade negotiations are proceeding at the same time, and reduced commodity subsidies could lead to lowered trade barriers in other countries. The global concerns of U.S. agriculture are as old as the first exports of colonial tobacco in 1608, Sumner noted, but the global interconnections are even more vital now.

Sumner: To get other countries to open their markets, the United States will have to reduce the production incentives built into our farm programs. It's a grand bargain (cutting subsidies to open markets), and our trade negotiators obviously can get more benefit for California agriculture the more they can open export markets for California products. Beneficiaries of lower trade barriers include the cotton and rice industries, which are also very dependent on subsidies. But, lower trade barriers are also a big win for other parts of California agriculture that do not get subsidies.

\section{Toward reform: Farm Bill politics}

Finally, participants discussed the steps leading to the enactment of the 2007 Farm Bill. Already, at least 18 months in advance of final legislation, a larger and more diverse collection of organized interests than usual is engaged in extensive jockeying to influence the terms of the bill. Fundamental reforms are in the air, making the process unusually complicated and lengthy.

The alliances are coming to the table for different reasons, but many of them believe that a change is coming, and so there are opportunities to shape things in a way that meets their needs.

Kawamura: And with specialty crops newly involved with the Farm Bill, congressional delegations from the affected states may get involved with those negotiations, which would be a huge swing in the nature of congressional participation.

\section{What's next?}

Considering this mix of issues and forces, it is still too early to discern the shape of the 2007 Farm Bill and its possible effects on California. The large national budget deficit makes it likely that this next bill will reduce current federal spending on agricultural and related programs. Almost all observers expect cuts, especially in commodity payments.

Other critical factors include current World Trade Organization (WTO) rules and ongoing negotiations over a new Agricultural Agreement. Some subsidies by the United States and other nations to their agricultural sectors produce "trade

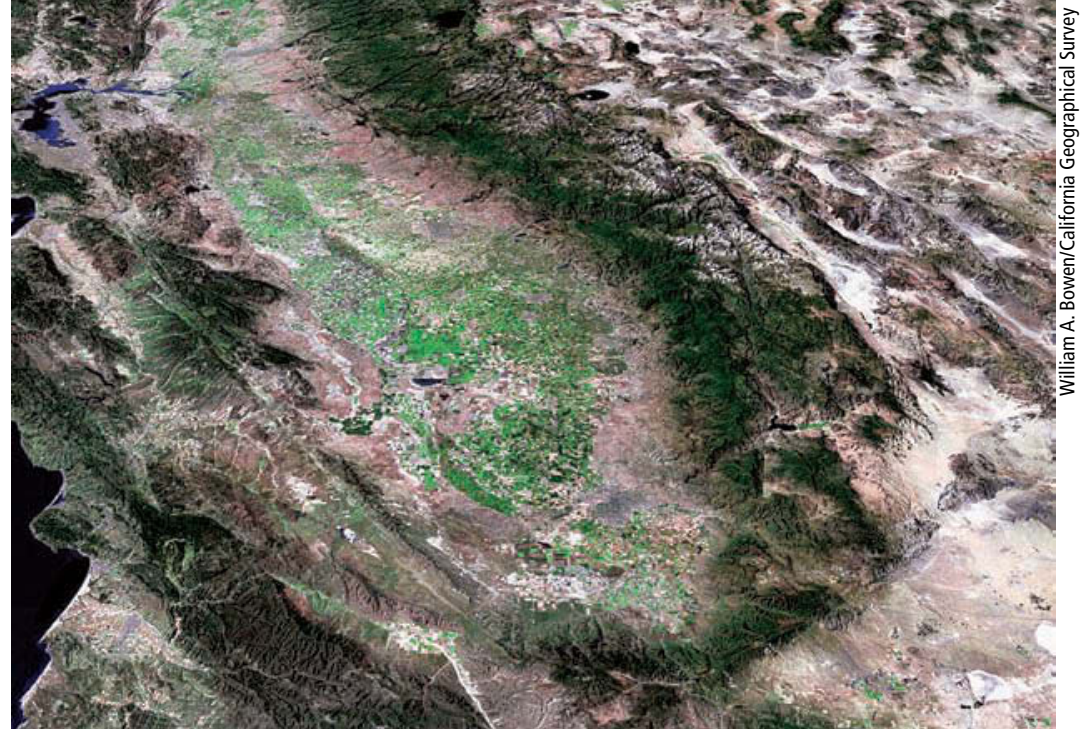

In the San Joaquin Valley, shown, a predominantly agricultural region is struggling with pressures from increasing population and sprawl development. Federal environmental and conservation law will continue to have an important impact on land use in rural and natural areas of California.

distortions"; these are vulnerable to challenge as violating the current WTO rules. Furthermore, the trade impact of commodity programs is the key issue currently delaying a final WTO agreement, now anticipated in 2007. The terms of the WTO agreement will certainly affect the amounts and details of commodity payments to U.S. farmers, as the U.S. government wants to ensure that federal farm policy is compatible with international obligations. Sumner noted that some voices in Congress and in the agricultural community are calling for a delay beyond 2007 to complete the upcoming Farm Bill, in order to allow sufficient time to absorb the new international rules.

TABLE 2. Payments to California farmers by major programs of USDA's Natural Resources Conservation Service, FY 2003*

\begin{tabular}{lc}
\hline Program & $\begin{array}{c}\text { Conservation } \\
\text { paymentst }\end{array}$ \\
\hline & $\begin{array}{c}\text { millions } \\
\text { Environmental Quality Incentives Program (EQIP) }\end{array}$ \\
Wetlands Reserve Program (WRP) & 19.9 \\
Conservation technical assistance & 18.9 \\
Ground and Surface Water Conservation Program & 11.5 \\
Klamath Basin Program & 6.9 \\
Farm and Ranch Lands Protection Program & 3.2 \\
Grassland Reserve Program & 2.3 \\
\hline * The table does not include payments made by USDA's Conservation \\
Reserve Program (about \$1.8 billion nationwide), which is a program of \\
the Farm Services Administration. \\
+ California ranked second nationwide with non-CRP conservation funding \\
of \$97.2 million, 15.4\% of national total; Texas ranked first nationwide, \\
with total conservation funding of \$118.4 million, 18.7\% of national \\
total. When CRP is included California ranks about 12th and had about \\
4\% of the national total. \\
Outlays fluctuate from year to year because of changing congressional \\
appropriations and allocation formulas.
\end{tabular}

